\title{
O přirozenosti - a výchově člověka
}

\section{Zuzana Svobodová}

Envigogika 12 (1) - Recenzované články/ Reviewed articles

Publikováno / Published 23. 7. 2017

DOI: $10.14712 / 18023061.542$

\begin{abstract}
Abstrakt
Článek "O přirozenosti - a výchově člověka" volně navazuje na otázky pokládané v prvním čísle ročníku 2016 tohoto časopisu (Envigogika 2016/XI/1), přičemž se zaměřuje na otázky po přirozenosti v kontextu výchovy a vzdělávání. Fenomény jako "výchova" a "přirozenost" ("kultura" a „přirozenost"), byly vnímány v napětí již v antice (PAIDEIA versus FYSIS, TECHNÉ versus FYSIS; cultura versus natura). $V$ promýšlení základů výchovy je toto napětí zdrojem tzv. výchovných antinomií (Fink 1992: 11-19). Autorka se v textu zaměřuje na rozum (LOGOS) a náklonnost (EROS, FILIA, AGAPÉ) jako "přirozenosti" fundující kultivaci člověka. Tyto přirozenosti má vychovaný odpovědně užít v pravém okamžiku (KAIRos). Pak má smysl hovořit o integraci a spoluutváření harmonického života - na základě přirozené diverzity, s užitím rozumu a náklonnosti, ve vhodné době.
\end{abstract}

\begin{abstract}
The article "On the Nature and Education of Man" follows up loosely on the questions put forward in the first issue of the 2016 volume of this journal (Envigogika 2016/XI/1), focusing on questions of (human) nature in the context of education and training. Already in the antiquity, the relation between phenomena such as "education" and "(human) nature" ("culture" and "nature") was perceived as a relation of tension (PAIDEIA vs. FYSIS, TECHNÉ vs. FYSIS, cultura vs. natura). When reflecting the fundamentals of education, this tension is a source of the so-called educational antinomies (Fink 1992: 11-19). In her contribution, Zuzana Svobodová focuses on reason (LOGOS) and affection (EROS, FILIA, AGAPÉ) as the kinds of "(human) nature" that are the foundations for cultivating human beings. The educated person is invited to use those (human) natures responsibly and at the right moment (KAIROS). Then it makes sense to consider the integration and co-creation of a life in harmony - based on natural diversity, using reason and affection, at an appropriate time.
\end{abstract}

\section{Klíčová slova} skost

přirozenost; umělé; logos; náklonnost; vztahovost; nelhostejnost; odpovědnost; lid-

\section{Keywords} humanity

(human) nature; artificial; logos; affection; relationship; indifference; responsibility; 


\section{Přirozené a umělé}

Přirozené, přirozeně, podle přirozenosti - všechna tato slova se užívají v češtině s pozitivní konotací. Patří ostatně k podstatě mnoha jiných jazyků, že "svět" , "život", „příroda" nesou samy o sobě pozitivní význam. Ptát se na stránkách časopisu zaměřeného environmentálně po tom, jakou hodnotu má pak ono „umělé" - ne-přirozené, nestvořené ani nezrozené, je snad př́padné. Jistě existovali a zřejmě existují jedinci i společnosti, které se takto neptají, nebot' svou odpověd' považují za konečnou. Nepatřím ani k těm, kteří by považovali všechno pocházející od činnosti člověka za špatné, ani k těm, kteří by považovali vše pocházející od člověka za lepší, než je (bylo) to přirozené. Považuji otázky po přirozeném za nedořešené a snad - dokud je přirozené přirozujícím se - za nedořešitelné, přesto ale za velmi podstatné je skrze „možnosti člověka” otevírat a snažit se podle nalezeného utvářet naše - lidské, kulturní - jednání, přičemž na tomto místě půjde především o výchovu, kterou považuji za kulturní jednání povýtce. Otázky po přirozeném považuji za podstatné právě proto, že člověk je sice jednou z bytostí tohoto světa, ale je jednající nejen na základě přirozenosti. Způsob, jakým člověk interpretuje fakta získaná popisem přirozujícího, ale také již výběr toho, co a jak je popisováno, ovlivňují, jak budeme jako lidé rozumět vlastnímu prostředí, co pro nás bude představovat pojem „svět”. Rozlišit zde (při tvorbě vnímání světa) striktně přirozené a umělé, není jednoduché, nebot' svět, prostředí, ve kterém žijeme, není jen objektem (tj. předmětem) našeho pozorování, ale je také (jedním) substrátem, základem našeho vlastního bytí.

Není nahodilé, že počátky fenomenologie jsou na našem území spojené s dílem „Přirozený svět jako filosofický problém", habilitačním spisem Jana Patočky z roku 1936. Patočka se zamýšlí nad pojetím přirozenosti s jasným zdůvodněním (podaným napríklad ve stati "Přirozený svět a fenomenologie" z roku 1967): „Problém »přirozeného světa «znikl výslovně $v$ pozitivistickém filosofickém prostředí, tj. v prostředí zaměřeném proti tradiční metafyzice mimo vědu i ve vědě; tam, kde se vyvozovaly důsledky z empiristické kritiky pojmů substance a kauzality, kde pozitivistický pojem fenomenálního a relativního poznání, které neproniká mimo obor senzuálních daností, a pozitivistický pojem jsoucna jako toho, co je prostě dáno bez dalších příměsí, těžil z krize mechanistického názoru moderní přírodovědy, k níž přes všechny úspěchy pozvolna docházelo ke konci 19 . století." ${ }^{1} \mathrm{~V}$ následujícím textu pak Patočka ukazuje, proč se tématem přirozeného světa je třeba zabývat jiným způsobem, jak to činí Edmund Husserl, který "objeví pod snahami moderního empirismu (a pozitivismu) jejich hlubší dno"2, a jak navazuje na Husserlův projekt také Patočka, který přichází s cílem metafyziku překonat a uchovat v hlubším smyslu ${ }^{3}$ a vede jej to mimo jiné k rozlišení zkušenosti, kterou činíme, a zkušenosti, kterou jsme. V závěru promýšlení tématu své habilitační práce po více než třiceti třech letech Patočka píše: „Třetí životní pohyb, ten, který je vưči prvním dvěma ve vazbě spojení a zatlačení, tedy v dialektické vazbě, objevuje tady podstatnou dimenzi přirozeného světa, tu, která není dána, uniká vněmu i vzpomínce, uniká věcné identifikaci, a přece tento svět podstatně podmiňuje. Tuto oblast jak pozitivisté, tak Husserl ve svých popisech a rozborech "přirozeného" světa našeho života pominuli." 4 Patočka tu, podobně jako jiní žáci Edmunda Husserla, navazuje na počátky fenomenologie, přičemž neváhá vyjít za jejího zakladatele: „Čeho Husserl mínil dosíci svou fenomenologic-

\footnotetext{
${ }^{1}$ Patočka, J. Fenomenologické spisy II, s. 202.

2 Patočka, J. Fenomenologické spisy II, s. 209.

${ }^{3}$ Srov. Patočka, J. Péče o duši I, s. 326.

${ }^{4}$ Patočka, J. Fenomenologické spisy II, s. 334.
} 
kou redukcí jako faktu, dosažitelného ve filosofické reflexi, je ve skutečnosti výsledek komunikace existencí: jejich přesah do řetězu bytostí, spojených nikoli vnějškovým poutem, bytostí, které nejsou ostrůvky života v moři objektivního jsoucna, nýbrž pro něž se věcná předmětnost vynořuje z oceánu bytí, v jehož službách komunikují. " ${ }^{5}$ Toto společenství odevzdanosti je společenstvím, které prošlo uvědoměním prvotní akceptace, přijetím, ale i sebeztrácením $v$ boji a práci, až došlo skrze obrat ${ }^{6} \mathrm{k}$ odevzdávání se $v$ oddané službě, $v$ níž bytost jest, nikoli jen činí zkušenost, v níž je člověk svobodný, vnímající (a žijící) smysl nezávislý na předmětném (naopak předmětné zakládající, fundující) ${ }^{7}$

\section{Rozum a náklonnost}

Za ony "možnosti člověka", kterými je možné otevírat otázky po přirozeném, považuji $v$ tomto textu především dvě mohutnosti člověka: rozumový um - nadání člověka uvažovat, myslet, promýšlet $v$ kontextech, kriticky hodnotit, tj. také díky paměti a schopnosti odhalovat vztahy věcí a na základě jejich kritického posouzení usuzovat, tedy nadání člověka zacházet s tím, co staří Řekové nazvali LoGos. Druhou mohutností, kterou zde považuji za "možnost člověka" účastnící se otevírání otázek po hodnotě přirozeného a nepřirozeného, je náklonnost, láska, prátelství, tedy zhruba to, co staří Řekové nazývali EROS, FILIA, AGAPÉ. Nebudu zde vytvářet nějaké taxonomie či typologie lásky, chci hovořit o této náklonnosti jako podstatném vztahu - jako o základu vztahovosti vůbec. Bez ní by byl člověk ke světu Ihostejný. Netvrdím, že ony tři řecké termíny jsou $v$ zásadě jedno, ale považuji za jejich základ otevřenost či otevřitelnost jedné bytosti druhému či druhým, tedy schopnost nebýt jen sám sobě.

Klasickou dvojicí mohutností, kterými bývá člověk vyčleňován nad říši živočichů, je sice rozum a vůle, ale přestože považuji vůli za klíčovou zejména ve výchově, právě pro účely promýšlení možností výchovy se mi jeví důležité upřednostnit nyní před promýšlením vůle fenomén lidské vztahovosti, nebot' vztahovost jednak může být projevem volního rozhodnutí, jednak člověka předchází - člověk je vždy již v nějakém vztahu, byt́ nereflektovaně - tedy vrženost do vztahu, či sítě vztahů člověka předchází, vztahovost předchází i jeho aktivní vztah k logu. Hlouběji než vidění je pohybování se, přibližování - zkušenost, kterou činíme, je podřízena zkušenosti, kterou jsme - a jen díky otevřenosti, vztahovosti, jsme schopni zkušenosti světa, připomíná Jan Patočka ${ }^{8}$.

Pokud je náklonnost základem vztahovosti, zbývá si klást otázku, nakolik je náklonnost přirozená. Tato vykloněnost či nakloněnost $k$ druhému a druhým má jistě co do činění $s$ přirozeností. Zde zkušenost ukazuje, jaká diverzita či různost je v náklonnosti lidí - ve způsobech i v intenzitě. A není projev náklonnosti u každého člověka jedinečný? Nepatř́ $k$ přirozenosti člověka, že projevuje náklonnost neopakovatelně, jedinečně, nezastupitelně? Jistě může být na základě reflexe náklonnost výrazně proměněna. Reflexí ale rozumíme

\footnotetext{
5 Tamtéž.

${ }^{6}$ Srov. Patočka, J. Fenomenologické spisy II, s. 333.

7 Srov. též Barbaras, R. Pohyb existence, s. 12-34.

${ }^{8}$ Srov. Patočka, J. Fenomenologické spisy II, s. 222: „Kontakt s druhými je prvotní, nejdůležitější komponenta centra přirozeného světa, jehož pưdou je země a periferií nebe. Kontakt s druhými je vlastní centrum našeho světa, dává mu jeho nejvlastnější obsah, ale též jeho hlavní smysl, možná dokonce i všecek smysl. Kontakt s druhými vytváří teprve vlastní prostředí, v němž člověk žije...". Srov. též Barbaras, R., Pohyb existence, s. 34.
} 
zpravidla náhled podle určitých pravidel, řádu, logu. Zdá se tedy, že zatímco v náklonnosti Ize spatřovat jedinečný projev přirozeného jednání člověka, v rozumnosti naopak Ize spatřovat př́klon $\mathrm{k}$ společnému řádu, který sdílíme $\mathrm{v}$ určité míre, podobně jako sdílíme jazyk, kterým spolu komunikujeme.

Dvě mohutnosti člověka - rozum a náklonnost - Ize nějakým (umělým) způsobem pojednávat - popisovat - odděleně, ale působí (přirozují se) pospolu, v člověku jako celku. Pouze pro účely porozumění - náhledu (THEORIA) - je možné se na ně ptát odděleně, ale ve skutečnosti - v jednání (PRAXIS) - jsou pospolu. Jakási vztahová rozumnost je v lidské přirozenosti, jak popsal již Aristotelés ve svém spisu o lidském uspořádání - Politika ${ }^{9}$. Člověku je dle Aristotela přirozené žít v obci, být její součástí, která se podílí na jejím životě. Pokud by celek již nežil, nemá ani smysl hovořit o člověku, jak byl dosud pojímán - pro toho, komu již celek není celkem, jehož je součástí, dle Aristotela platí, že je jako bůh (kdo společenství nepotřebuje), nebo jako zvíre (kdo společenství - na rozdíl od tlupy, stáda, hejna apod. není schopen). Lidsky žít znamená tedy dle Aristotela nacházet své uplatnění v životě pro obec, v obci, skrze obec, v životě podle práva a zákonů ${ }^{10}$, ve vzájemnosti - utváření svého života ve vzájemnosti a pro vzájemné dobro je podle Aristotela typický rys života v PoLIS, v obci jako útvaru, který člověku a jeho lidskosti předchází.

Také Komenskému je základem lidskosti udílení si vzájemně z toho dobrého. V díle Orbis sensualium pictus vykresluje lidskost (humanitas) s popiskem začínajícím slovy: „Lidé jsou stvořeni (učiněni) ke společným výhodám; proto mají býti lidští."11 Opakem této nakloněnosti k druhému a vzájemného udílení si toho dobrého je pak boj jednoho s druhým, násilí, touha po přemožení, tedy naklonění ve zlém, s cílem pře-moci, nikoli po-moci.

\section{Kairos - vhodná doba, pravý okamžik}

Když Jan Patočka pět dní před svou smrtí psal o úmyslu Charty 77 jako o úmyslu pedagogickém, klíčová slova vložil do samého závěru tohoto jednoho ze svých dvou posledních textů: "nejdůležitější je pochopit pravý okamžik a přijít včas"12. Lidsky nejdůležitější. $\mathrm{K}$ tomuto cíli by měla směřovat veškerá výchova, kterou na sebe $\mathrm{v}$ posledku musí vzít každý sám. $\mathrm{K}$ tomuto cíli má mirrit každý člověk, který usiluje být lidský, $\mathrm{k}$ tomuto cíli mají mírit vychovatelé, pedagogové.

Existuje-li dnes samostatný studijní obor sociální pedagogika, pak považuji za její jádro právě tento úkol: napomáhání k porozumění pravému okamžiku, času KAIRos, který se vlamuje do stále stejně plynoucího času CHRONOS, činí průlom do jednoho řádu, otevírá jednu homogenitu pro nové, jiné, dosud neznámé - a hledat cesty, jak přicházet, jak klenout spo-

\footnotetext{
${ }^{9}$ Aristotelés, Politika, 1253a 2nn.

${ }^{10}$ Aristotelés, Politika, 1253a 34.

${ }^{11}$ Komenský, J.A. Orbis sensualium pictus, CXV, s. 248. Srov. Komenský, J. A. DJAK, CXV, s. 216.

${ }^{12}$ Patočka, J. Češi I, s. 443n: „Charta nezamýšlela nikdy působit jinak než pedagogicky. Ale pedagogicky působit - co to znamená? Vychovávat se může pouze každý sám, ovšem často stržen př́kladem; též varován špatnými výsledky a poučen rozmluvou, diskuzí. Výchova, to znamená pochopit, že je něco jiného $v$ životě než strach a prospěch... Charta by chtěla, ... Aby si lidé uvědomovali, že na světě nerozhodují peníze ani síla, ba ani nadání, nýbrž že nejdůležitější je pochopit pravý okamžik a přijít včas."
} 
lečenství, učit se novému souladu, nové harmonii, která bude obsahovat nové, dosud nesIyšené a nezaznělé. Bez porozumění pro to, co znamená „pravý okamžik”, se může vychovatel dopouštět nepřirozeného násilí, tedy opaku toho, co by měla znamenat výchova (PAIDEIA, educatio, humanitas - přispění člověku $k$ jeho lidskosti, pomoc na cestě $z$ ne-znalosti k po-rozum-ění). Pokud by sociální pedagogika vnímala sama sebe jen jako nástroj určité societas k zachování dosavadních pořádků, pak by nešlo o výchovu, ale o uchovávání (dosavadních pořádků, stavů), o chov (jako u stáda, hejna apod.). Je-li sociální pedagog podle současného chápání $v$ naší zemi vychovatelem, pak je jeho klíčovou rolí porozumět diverzitě (různosti, nehomogenitě) přirozeného jako pozitivnímu základu pro rozvíjení, růst lidskosti ve společnosti, ke kterému má přispívat svou profesí (z latinského professio). Pokud by měl vychovatel porozumění pouze pro homogenní čas CHRONOS, pak by nikdy nerozuměl oné Patočkově výzvě $\mathrm{k}$ pedagogickému působení, oné výzvě člověku, která se týká toho podstatně lidského („pochopit pravý okamžik a přijít včas"), totiž lidské odpovědnosti ve světě. Pak teprve, po pochopení pozitivity (potence přínosu) této přirozené různosti v prostředí (tj. času, prostoru i jejich "obsahu") výchovy, je možné hledat cesty integrace, která má svůj původ (základ) v integritě.

Emmanuel Lévinas hovořil např́klad v přednáškách vydaných jako „Čas a jiné" o diachronii času, o času jako vztahu k tomu, co se nedá přizpůsobit zkušeností, o ne-koincidenci, in-adekvaci, jako dobru prvotní sociality ${ }^{13}$.

\section{Od integrity $\mathbf{k}$ integraci - a harmonii}

Je integrita přirozená? V lidském světě, který se snaží utvářet např́klad Evropská unie, soudě podle Listiny základních práv Evropské unie z roku 2007 (která nahradila listinu ze 7. prosince 2000), ano: „Article 3: Right to the integrity of the person. 1 . Everyone has the right to respect for his or her physical and mental integrity." (Cituji z anglického znění, nebot v oficiálním českém překladu je termín „integrity" přeložen jako "nedotknutelnost".) To, že je na toto právo výslovně upozorněno, je samožrejmě znamením reflexe, že se porušování integrity člověka dělo a mnohde ještě děje, nemá to však být občany Evropské unie dovolováno. Pro mnohé lidi dosud není možné žít tak, že je zachována integrita jejich osobnosti. Je tedy úkolem výchovy - a patří to k náplni profese např́klad konkrétně sociálních pedagogů - přispívat $k$ integritě, utvářet takto svět, společenství, které je $v$ souladu, přestože není homogenní. Jak to může činit?

Není to nová otázka, již antičtí myslitelé si ji kladli. Aristotelés ji řeší například ve své Politice. Zcela prakticky postupuje až k návrhu a zdůvodnění konkrétních metod. Zejména pro toho, který nečte pozorně dílo Politiky $\vee$ jeho vnitřní souvislosti, bude asi překvapující, že Aristotelés viděl jako nejdůležitější vyučovací předmět na veřejných školách hudební výchovu. Právě pojednáním o konkrétní náplni obsahu vyučovacího předmětu hudební výchova, o jeho metodách a prostředcích, celý spis Politiky vrcholí. Aristotelés hledal způsob, jak přispět $\mathrm{k}$ uspořádání obce (PoLIS), aby byla nejlepší. To nejlepší je vnímáno jako blaženost (řecky EUDAIMONIA, do angličtiny dnes překládáno jako well-being). Nejvyšší blaženosti dosáhne obec tehdy, když každý občan bude blažený ${ }^{14}$, k čemuž napomáhá ctnostný život

\footnotetext{
13 Lévinas, E. Čas a jiné, s. 14-15.

${ }^{14}$ Srov. Aristotelés, Politika 1331b 25, 39nn.
} 
(nejen zevnější dobra) ${ }^{15}$. Občan dosáhne blaženosti, když bude na základě přirozenosti rozvíjet dobré zvyky a žít podle rozumu (to může dle Aristotela činit jen člověk, na rozdíl od jiných živočichů, kteří žijí jen podle přirozenosti). $\mathrm{K}$ tomu má sloužit výchova ${ }^{16}$, a to nejen soukromá, ale - jde-li o nejlepší obec - výchova veřejná a společná. Mezi vyučovanými předměty ${ }^{17}$ - jako nástroji výchovy - mají místo ty, které jsou nutné, dále ty, které jsou užitečné, ale nejvyšší hodnotu dle Aristotela mají ty, které nejsou ani nutné ani užitečné (ve smyslu „prostředečné", zaměřené k využití), ale ty, které jsou určeny pro život ve volném čase, nikoli pro boj, ale pro čas míru, prázdně (scHoLÉ) $)^{18}$. Takovým předmětem je hudební výchova - její výuka nespočívá v nabytí užitečných nebo nutných znalostí, ale k blaženosti ducha, k radosti dobré mysli ${ }^{19}$; vzdělávání $v$ hudbě není pro nějakou užitečnost či potřebu ${ }^{20}$, ale má být součástí výchovy, protože je ušlechtilé a krásné ${ }^{21}$. $Z$ těchto důvodů věnuje Aristotelés hudební výchově největší prostor ve svém pojednání o vyučovacích předmětech a - jak již bylo uvedeno výše - také tímto pojednáním o hudbě, jako základu pro harmonický život, život v harmonii a s harmonií, celou svou Politiku, spis o náležitém uspořádání obce, končí. Je totiž přesvědčen o tom, že podaříl-li se výchovou přivést občany $\mathrm{k}$ harmonii, není třeba se bát o život v obci, nebot' harmonický život bude blažený, dobrý a krásný.

Je tato Aristotelova představa z Politiky (která zde výslovně navazuje na Etiku Níkomachovu - EN X7) utopií? Nepřesvědčuje skutečnost, že v sociologických průzkumech o činnostech ve volném čase ${ }^{22}$ je dlouhodobě na předních místech poslouchání hudby, o tom, že také dnešní člověk, podobně jako již homérský (nebot' Aristotelés zde navazuje výslovně na starší tradici, která vysoce ocenila výchovnou roli hudby), prožívá radost tehdy, kdy vnímá - či prožívá - soulad, harmonii?

Lze si představit př́spěvky $\mathrm{k}$ harmonickému utváření života i prostřednictvím jiných činností, nejen kvalitní hudební výchovy. Podstatné je, v čem se liší přístupy výchov, které podporují toto harmonické spoluutváření od přístupů, které se na tomto utváření nepodílejí. Zdůrazňování kompetitivnosti, soutěživosti, měření a poměřování dosažených výsledků, patrně nebude prímo podporovat pochopení pozitivní role diverzity. Soutěživost bude mít ale také jisté místo ve výchově, ovšem jen v rámci zjišt́ování stavu, cílem však musí být na základě zjištěného stavu přispívat $k$ utváření harmonického života, kompetice nemůže být posledním cílem, ale jen jedním z prostředků výchovy k harmonii. Maximální možný rozvoj každého člověka je jistě dobrým cílem v rámci výchovy a vzdělávání, ale není-li veden žák k tomu, že tento potenciál má hrát ve společnosti zcela specifickou, nedelegovatelnou roli a přispívat tak $\mathrm{k}$ souladu, je něco $\mathrm{z}$ možností veřejného vzdělávání zanedbáno. Eugen Fink připomínal antinomičnost skutečné výchovy, zde pak např́klad napětí mezi výchovou k profesi a výchovou k lidství nemůžeme zrušit, chceme-li zachovat podstatu výchovy. ${ }^{23}$ Nelze

\footnotetext{
15 Srov. Aristotelés, Politika 1332a 1-33.

${ }^{16}$ Srov. Aristotelés, Politika 1332b 10n.

17 Srov. Aristotelés, Politika 1337b 24-28.

${ }^{18}$ Srov. Aristotelés, Politika 1334a 5, 10, 14-25, 1337b 14, 33-36, 1338a 1, 11, 23n.

19 Srov. Aristotelés, Politika 1338a 27nn.

${ }^{20}$ Srov. Aristotelés, Politika 1338a 31.

21 Srov. Aristotelés, Politika 1338a 33.

22 Srov. např. http://www.vyzkum-mladez.cz/zprava/1157352599.pdf, http://www.promenyceskespolecnosti.cz/aktuality/aktualita22/Jak Cesi travi cas TK 20-06-2016.pdf, s. 16.

${ }^{23}$ Srov. Fink, E. Natur, Freiheit, Welt, s. 11-19.
} 
vychovávat člověka bez vztahu k jeho poslání ve společenství, bez oné zakládající nakloněnosti. Pramenem těchto antinomií je již antickými mysliteli objevené napětí mezi přirozeným a kulturním (FYSIS a TECHNÉ, prípadně mezi FYSIS a PAIDEIA, nebo u latiníků mezi natura a cultura).

\section{Závěr}

Rozum(nost) a náklonnost, dvě mohutnosti člověka, které působí v jeho životě pospolu, Ize vnímat jako potence, kterými člověk utváří své lidství, kterými se účastní na přirozování, uskutečňování svého bytí, na zkušenosti, kterou jest. Otevřenost člověka druhým a světu je podmínkou uskutečňování náklonnosti, která je člověku prvotním darem umožňujícím jeho život a domov, ale též úkolem, totiž aby svou náklonnost projevoval v prostředí, ve kterém má působit, odpovědně. Odpovědnost takového pobývání ve světě, projevování náklonnosti, otevřenosti, vztahovosti, neznamená jednat nahodile, ale na základě pozorného naslouchání, vnímání a promýšlení zkušenosti, kterou jsme, jednat ve světě v pravý čas, totiž vhodně, $v$ souladu $s$ diachronním vstupem nového, jiného, které současný přirozující se svět očekává a potřebuje, aby mohl být harmonickým celkem.

Harmonický život je projevem úspěšné integrace, tedy procesu, $v$ němž se různost podařilo uchovat a přivést $k$ projevu $v$ celku společnosti, vytvořil se tím pestřejší svět, $\checkmark$ němž je možné žít a dál spolupracovat na utváření přirozujícího.

Akreditují-li se dnes obory jako sociální pedagogika, je pro jejich garanty a vyučující výzvou promýšlet (tj. nestačí jen definovat) základní možnosti a meze výchovy a klást si otázku po roli sociální pedagogiky přestože - či právě protože - žijeme již - na rozdíl od doby vzniku Charty 77 - v demokratické společnosti, která se hlásí k základním hodnotám vyjádřeným (např́klad) v Listině základních práv Evropské unie. Pak by mělo být v naší společnosti přirozené, aby i školní výchova a vzdělávání rozvíjely integritu žáků, na jejímž základě může růst integrace a harmonie - soulad ve společnosti, který bude vnímán jako krásný a dobrý. Již Aristotelés upozorňoval v tomto ohledu na velký potenciál hudební výchovy. Podaří-li se naší „znalostní společnosti” dohlédnout k těmto zdrojům a skutečně z nich ve své teorii a praxi výchovy čerpat, máme snad - jako její členové i celek společnosti naději na přirozený rozvoj.

\section{Literatura:}

- Aristotelés. (2009). Politika. Praha: Rezek. ISBN 978 80-86027-30-2.

- Barbaras, R. (2016). Pohyb existence: Studie k fenomenologii Jana Patočky. Červený Kostelec: Pavel Mervart.

- Fink, E. (1992). Natur, Freiheit, Welt. Philosophie der Erziehung. Würzburg.

- Institut dětí a mládeže MŠMT ČR. Děti, mládež a volný čas (Vybrané aspekty problému). Zpracoval O. Jíra. Retrieved from: http://www.vyzkum-mladez.cz/zprava/1157352599.pdf

- Komenský, J. A. (2001). Orbis sensualium pictus. Praha: Levné knihy KMa.

- Komenský, J. A. (1970). Orbis sensualium pictus. In: Dílo Jana Amose Komenského. [DJAK] Opera omnia. Sv. 17. Praha: Academia. 
- Lévinas, E. (1997). Čas a jiné. Praha: Dauphin.

- Patočka, J. (2006). Češi I. Sebrané spisy Jana Patočky. Sv. 12. Praha: OIKOYMENH.

- Patočka, J. (2009). Fenomenologické spisy II. Sebrané spisy Jana Patočky. Sv. 7. Praha: OIKOYMENH.

- Sociologický ústav Akademie věd ČR. (2016). Proměny české společnosti. Jak Češi tráví čas? Výsledky 1. ročníku výzkumu Proměny české společnosti 2015. Materiál k tiskové konferenci 20. 6. 2016. Retrieved from: http://www.promenyceskespolecnosti.cz/aktuality/aktualita22/Jak Cesi travi cas TK 20-06-2016.pdf

- Listina základních práv Evropské unie. (2007). Retrieved from: http://eur-lex.europa.eu/legal-content/CS/TXT/?uri=CELEX\%3A12012P\%2FTXT 